\title{
SYNTHESIS, CRYSTAL STRUCTURE, DFT AND ANTIBACTERIAL ACTIVITY STUDIES OF (E)-2-BENZYL-3- (FURAN-3-YL)-6,7-DIMETHOXY-4-(2-PHENYL-1H-INDEN-1-YLIDENE)-1,2,3,4-TETRAHYDROISOQUINOLINE
}

\author{
S. MURUGAVEL ${ }^{1 *}$, N. MANIKANDAN ${ }^{2}$, D. LAKSHMANAN ${ }^{3}$, KANAGARAJ NAVEEN ${ }^{4}$, \\ PARAMASIVAN THIRUMALAI PERUMAL ${ }^{4}$
}

\author{
$I^{*}$ Department of Physics, Thanthai Periyar Government Institute of Technology, Vellore-632 002, Tamilnadu, India \\ ${ }^{2}$ Department of Physics, Bharathidasan Engineering college, Nattrampallii, Vellore - 635 854, Tamilnadu, India \\ ${ }^{3}$ Department of Physics, C. Abdul Hakeem College of Engineering \& Technology, Melvisharam, Vellore-632 509, Tamilnadu, India \\ ${ }^{4}$ Organic Chemistry Division, CSIR - Central Leather Research Institute, Adyar, Chennai 600020, India, Tamilnadu, India
}

\begin{abstract}
The title compound (I), (E)-2-benzyl-3-(furan-3-yl)-6,7-dimethoxy-4-(2-phenyl-1H-inden-1-ylidene)-1,2,3,4-tetrahydroisoquinoline $\left(\mathrm{C}_{37} \mathrm{H}_{31} \mathrm{NO}_{3}\right)$, was synthesized and structurally characterized by elemental analysis, ${ }^{1} \mathrm{H}$ NMR and ${ }^{13} \mathrm{C}$ NMR and single crystal X-ray diffraction. In the compound, the $\mathrm{N}-$ containing six-membered ring of the tetrahydroisoquinoline unit adopts a distorted half-chair conformation. In the crystal structure, supramolecular chains mediated by $\mathrm{C}-\mathrm{H}$... O contacts along the $\mathrm{b}$-axis are linked into a double layer via $\mathrm{C}-\mathrm{H} \ldots \pi$ hydrogen bonds. The resulting double layer stacks along the c-axis without any specific interactions. The molecular geometry was also optimized using density functional theory using (DFT/B3LYP) method with the 6-311G(d,p) basis set and compared with the experimental data. In addition to the optimized geometrical structure, molecular orbital, molecular electrostatic potential (MEP) and chemical reactivity studies of the compound have been investigated by using DFT. The antibacterial activity of the compound for various concentrations were determined against eight test pathogens Bacillus cerus, Escherichia coli, Pseudomonas aeruginosa, Staphylococcus aureus, Acinetobacter baumannii, Staphylococcus epidermidis, Klebsiella pneumoniae and Proteus vulgaris. The results revealed that the compound exhibited good to moderate antibacterial activity.
\end{abstract}

Key Words: X-ray structure determination; Hydrogen bonds; DFT calculations;MEP; antibacterial activity.

\section{INTRODUCTION}

Compounds containing tetrahydroisoquinoline fragment in their structure display a broad spectrum of biological activities. In particular, derivatives of this type have been recently recognized as being G-protein-coupled receptor 40 (GPR40) antagonists ${ }^{1}$. The tetrahydroisoquinoline derivatives have attracted great attention in recent years due to their neurotoxicity ${ }^{2,3}$ antitumor activities, ${ }^{4,5}$, and antimicrobial activity ${ }^{6,7}$. The title compound has been synthesized by our co-authors ${ }^{8}$. Here we present the crystal structure of (E)-2-benzyl-3-(furan-3-yl)-6,7-dimethoxy-4-(2-phenyl-1H-inden-1-ylidene)1,2,3,4-tetrahydroisoquinoline (I), $\mathrm{C}_{37} \mathrm{H}_{31} \mathrm{NO}_{3}$. Literature survey reveals that so for there is no experimental, theoretical and antibacterial studies for the title compound. In recent years, density functional theory (DFT) has become an increasingly useful tool for theoretical studies. The success of DFT is mainly due to the fact that it describes small molecules more reliably than HartreeFock theory. It is also computationally less demanding than wave function based methods with inclusion of electron correlation ${ }^{9,10}$. Thus, in order to characterize the correlation between molecular structure and macroscopic properties in the studied compound, it seems to be essential to undertake a detailed comparative study of the isolated molecule and the solid state unit. In this paper, a concerted approach by X-ray crystallography and DFT calculation was used, which takes advantage of both the high interpretative power of the theoretical studies and the precision and reliability of the experimental method. Also, DFT is a powerful mathematical algorithm which is a useful tool to provide sets of quantum chemical descriptors that helps for finding suitable correlations for biological activities of various classes of organic compounds and their derivatives.

In this paper, we report the synthesis, crystal structure and antibacterial activity of (E)-2-benzyl-3-(furan-3-yl)-6,7-dimethoxy-4-(2-phenyl-1Hinden-1-ylidene)-1,2,3,4-tetrahydroisoquinoline $\left(\mathrm{C}_{37} \mathrm{H}_{31} \mathrm{NO}_{3}\right)$, as well as theoretical studies using the DFT(B3LYP) method and 6-311G(d,p) basis set. The aim of the present work was to describe and characterize the molecular structure and some electronic structure properties of the title compound, both experimentally and theoretically. We also make comparisons between experimental and calculated values. Further the title compound has been screened for antibacterial activity against Bacillus cerus, Escherichia coli, Pseudomonas aeruginosa, Staphylococcus aureus, Acinetobacter baumannii, Staphylococcus epidermidis, Klebsiella pneumoniae and Proteus vulgaris at three different concentrations 25,50 and $75 \mu \mathrm{g} / \mathrm{ml}$. The results were evaluated by measuring the inhibition zones diameter in millimeters and were compared with the standard antibiotic ciprofloxacin $(25 \mu \mathrm{g} / \mathrm{ml})$.
2. Experimental and Computational Methods 2.1 Synthesis of (I)
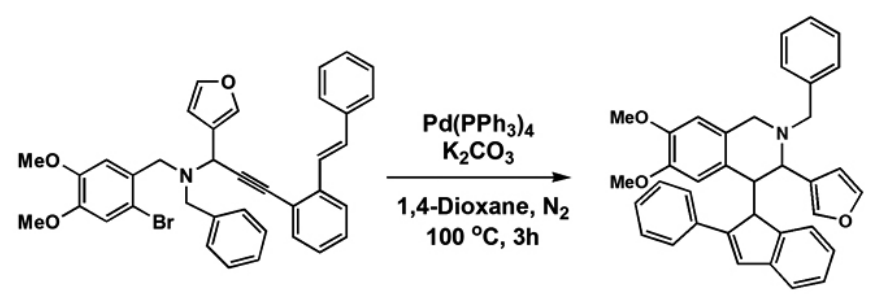
(I)

Scheme1 : Reaction scheme and chemical diagram of the title compound

The title compound (I) was obtained according to the reaction scheme-I. A solution of (E)-N-benzyl-N-(2-bromo-4,5-dimethoxybenzyl)-1-(furan-3-yl)3-(2-styrylphenyl)prop-2-yn-1-amine $(0.3 \mathrm{mmol})$ in 1,4 -dioxane $(4 \mathrm{~mL})$ was added to a mixture of $\mathrm{Pd}\left(\mathrm{PPh}_{3}\right)_{4}(0.03 \mathrm{mmol}, 10 \mathrm{~mol}-\%)$ and $\mathrm{K}_{2} \mathrm{CO}_{3}(0.15 \mathrm{mmol})$ in a clean, dry, two-necked round-bottomed flask under a $\mathrm{N}_{2}$ atmosphere. The reaction mixture was stirred at $100{ }^{\circ} \mathrm{C}$ for $3 \mathrm{~h}$. Then, the reaction mixture was cooled to room temperature and ethyl acetate $(15 \mathrm{~mL})$ and water $(3-15 \mathrm{~mL})$ were added. The organic layer was separated, dried with anhydrous $\mathrm{Na}_{2} \mathrm{SO}_{4}$, and concentrated under reduced pressure. The crude material was purified by column chromatography (silica gel, $5-40 \%$ petroleum ether/ethyl acetate) to afford the title compound. Single crystals of the title compound (I), suitable for single crystal X-ray diffraction studies have been grown in an ethanolic solution by slow evaporation of the solvent at room temperature and collected (yield $\left(88 \%\right.$ ) , m.p. $176-178{ }^{\circ} \mathrm{C}$ ).

The Nuclear magnetic resonance spectra $\left({ }^{1} \mathrm{H}\right.$ NMR and ${ }^{13} \mathrm{C}$ NMR) were recorded in $\mathrm{CDCl}_{3}$ on Bruker NMR $400 \mathrm{MHz}$ spectrometer and the chemical shifts are reported as $\delta$ values in parts per million (ppm) relative to tetramethylsilane, with $J$ values in Hertz. The splitting patterns in ${ }^{1} \mathrm{H}$ NMR spectra are reported as follows: $\mathrm{s}=$ singlet; $\mathrm{d}=$ doublet; $\mathrm{br} \mathrm{s}=$ broad singlet; $\mathrm{br}$ $\mathrm{d}=$ broad doublet; $\mathrm{m}=$ multiplet. ${ }^{13} \mathrm{C}$ NMR data are reported with the solvent peak $\left(\mathrm{CDCl}_{3}=100.0 \mathrm{MHz}\right)$ as the internal standard.

Yellow solid; m.p.: $176-178{ }^{\circ} \mathrm{C}$; Yield: $88 \%$; ${ }^{1} \mathrm{H}$ NMR $(400 \mathrm{MHz}$, CDCl $): \delta=7.39-7.33(\mathrm{~m}, 5 \mathrm{H}, \mathrm{Ar}-H), 7.29-7.23(\mathrm{~m}, 5 \mathrm{H}, \mathrm{Ar}-H), 7.18(\mathrm{t}, J$ $=8.00 \mathrm{~Hz}, 1 \mathrm{H}, \mathrm{Ar}-H), 7.09-7.00(\mathrm{~m}, 6 \mathrm{H}, \mathrm{Ar}-H), 6.43(\mathrm{~s}, 1 \mathrm{H}, \mathrm{Ar}-H), 6.42(\mathrm{~s}$, $1 \mathrm{H}, \mathrm{Ar}-H), 6.28(\mathrm{~s}, 1 \mathrm{H}, \mathrm{Ar}-H), 5.81(\mathrm{~s}, 1 \mathrm{H},-\mathrm{CH}), 4.10(\mathrm{~d}, J=12.00 \mathrm{~Hz}, 1 \mathrm{H}$, $\left.-\mathrm{CH}_{2}\right), 4.00\left(\mathrm{~d}, J=12.00 \mathrm{~Hz}, 1 \mathrm{H},-\mathrm{CH}_{2}\right), 3.83\left(\mathrm{~d}, J=16.00 \mathrm{~Hz}, 1 \mathrm{H},-\mathrm{CH}_{2}\right), 3.76$ $-3.72\left(\mathrm{~m}, 4 \mathrm{H},-\mathrm{CH}_{2},-\mathrm{OCH}_{3}\right), 3.42\left(\mathrm{~s}, 3 \mathrm{H},-\mathrm{OCH}_{3}\right)$ ppm; ${ }^{13} \mathbf{C}$ NMR (100 MHz, 
$\left.\mathbf{C D C l}_{3}\right): \delta=150.19,146.29,143.04,142.97,142.89,141.69,141.66,139.01$, $138.74,137.29,133.97,133.45,128.88,128.86,128.71,128.35,127.65$, $127.19,126.77,126.21,125.29,125.06,123.40,122.04,120.97,116.90$, $110.88,107.55,59.63,58.59,55.69,55.36,48.91 \mathrm{ppm}$.

2.2 X-ray Crystallography

Crystal of the title compound having approximate dimension $0.30 \times 0.26 \times 0.20 \mathrm{~mm}^{3}$ was mounted on a glass fiber using cyanoacrylate adhesive. All measurement were made on a BrukerAXSKapppa Apex II single crystal X-ray diffractometer using graphite mono-chromated $\mathrm{MoK} \alpha(\lambda$ $=0.71073 \AA$ ) radiation and CCD detector. Diffraction data were collected at room temperature by the $\omega$-scan technique. Accurate unit cell parameters and orientation matrix were obtained by a least-squares fit of several high angle reflections in the ranges $2.12^{\circ}<\theta<28.16^{\circ}$ for the title compound. The unit cell parameters were determined for 36 frames measured $\left(0.5^{\circ} \mathrm{phi}-\mathrm{scan}\right)$ from three different crystallographic zones and using the method of difference vectors. The intensity data were collected with an average four-fold redundancy per reflection and optimum resolution $(0.75 \AA)$. The intensity data collection, frames integration, Lorentz-polarization correction and decay correction were done using SAINT-NT (version 7.06a) software. Empirical absorption correction (multi-scan) was performed using SADABS ${ }^{11}$ program. The structure was solved by direct methods using SHELXS- $97^{12}$ implemented in WinGX ${ }^{13}$ program suit. The refinement was carried out by full-matrix leastsquare method on the positional and anisotropic temperature parameters of the non-hydrogen atoms, using SHELXL-97 ${ }^{14}$. All the $\mathrm{H}$ atoms were positioned geometrically and constrained to ride on their parent atom with $\mathrm{C}-\mathrm{H}=$ 0.93-0.97 $\AA$ and with $\mathrm{U}_{\text {iso }}(\mathrm{H})=1.5 \mathrm{U}_{\mathrm{eq}}$ for methyl $\mathrm{H}$ atoms and $1.2 \mathrm{U}_{\mathrm{eq}}(\mathrm{C})$ for

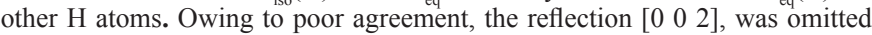
from the final cycles of refinement. The general-purpose crystallography tool PLATON ${ }^{15}$, ORTEP ${ }^{16}$ and MERCURY ${ }^{17}$ were used for structure analysis and presentation of the results.

\subsection{Computational Details}

The molecular structure of the compound in ground state (in vacuo) was optimized using density functional theory DFT (B3LYP ${ }^{18,19}$ method with the $6-311 \mathrm{G}(\mathrm{d}, \mathrm{p})^{20}$ basis sets. All the calculations were performed without specifying any symmetry for the title molecule by using GaussView molecular visualization program ${ }^{21}$ and Gaussian 03 program package ${ }^{22}$. The optimized geometrical parameters were calculated using Gaussian 03W package and Gauss View 03 program has been used to construct optimized molecular geometry.

\subsection{Antibacterial test}

Antibacterial susceptibility test was carried out using Kirby-bauer disk diffusion method as per CLSI M38-A guidelines ${ }^{23}$. The synthesized compound was dissolved in DMSO at various concentrations $(25,50$ and $75 \mu \mathrm{g} / \mathrm{ml})$ and tested against selected bacterial pathogens. Suspension of bacterial isolates was adjusted to $0.5 \mathrm{McF}$ arland standards in $0.85 \%$ saline (suspension will contain approximately $4 \times 10^{8} \mathrm{CFU} / \mathrm{ml}$ ) and lawn culture was spread using sterile swabs on Muller Hinton agar media (Hi-media, Mumbai). Wells $(6 \mathrm{~mm} /$ $\mathrm{dm}, 2 \mathrm{~cm}$ apart) were bored upon the lawn culture of the agar media using a sterile borer. Test compound $(25,50$ and $75 \mu \mathrm{g} / \mathrm{ml})$ were loaded to the wells under aseptic conditions and the plates were incubated at $37^{\circ} \mathrm{C}$ for 24 hours. Presence of inhibition zones surrounding each well evidenced antimicrobial activity. The antimicrobial activity was evaluated by measuring the inhibition zones diameter in millimeters. Each experiment was repeated three times and the mean of inhibitory zones were recorded.

Tests strains were procured from MTCC, INTECH, Chandigarh, India. They include Bacillus cerus (MTCC 430), Escherichia coli (MTCC 443), Pseudomonas aeruginosa (MTCC 1435), Staphylococcus aureus (MTCC 10623), Acinetobacter baumannii (MTCC 1425), Staphylococcus epidermidis (MTCC 10623), Klebsiella pneumoniae (MTCC 432) and Proteus vulgaris (MTCC 742). Standard antibiotic ciprofloxacin $(25 \mu \mathrm{g})$ was used as positive control to perform the test.

\section{RESULTS AND DISCUSSION}

\subsection{Description of Crystal structure}

The displacement ellipsoid plot and theoretical geometry structure with the atom-numbering scheme for compound (I) is shown in Fig. 1. The compound crystallizes in the monoclinic system, space group P21/c with cell constants: $\mathrm{a}=11.2121(4) \AA, \mathrm{b}=10.4797(3) \AA, \mathrm{c}=24.4375(9) \AA, \alpha=\gamma=90.0^{\circ}, \beta=$ $98.174(2)^{\circ}, V=2842.22(17) \AA^{3}, Z=4$. Details of the data collection, crystal parameters and refinement process of compound (I) are given in Table 1.
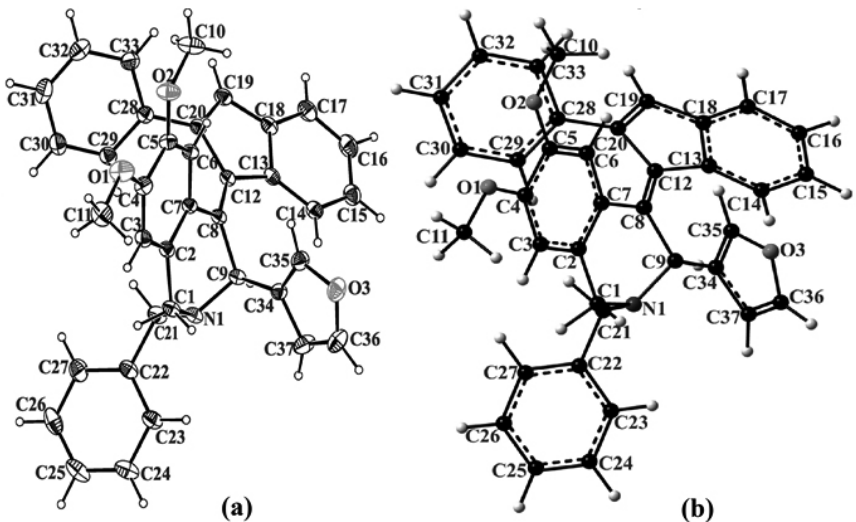

Figure 1: (a) View of title compound showing the atom-numbering scheme. Displacement ellipsoids for the non- $\mathrm{H}$ atoms are drawn at the $20 \%$ probability level. The $\mathrm{H}$ atoms are presented with spheres with arbitrary radii. (b) The theoretical geometric structure of the title compound (B3LYP/6$311 \mathrm{G}(\mathrm{d}, \mathrm{p})$ level).

The N-containing six-membered ring of the tetrahydroisoquinoline unit adopts a distorted half-chair confirmation, with the local two-fold axis passing through the midpoint of the $(\mathrm{C} 2-\mathrm{C} 7)$ and $(\mathrm{C} 9-\mathrm{N} 1)$ bonds. The asymmetry parameter $\Delta \mathrm{C}_{2}[\mathrm{C} 2-\mathrm{C} 7]^{24}$ is $12.35(16)^{\circ}$ and the puckering parameters ${ }^{25} \mathrm{Q}, \theta$ and $\varphi$ are $0.4840(13) \AA, 128.18(17)^{\circ}$ and $135.6(2)^{\circ}$, respectively. The essentially planar furan ring $(\mathrm{O} 3 / \mathrm{C} 34-\mathrm{C} 37)$ [maximum deviation $=-0.006(1) \AA$ for the $\mathrm{C} 36$ atom] is equatorially attached to the tetrahydroisoquinoline unit. The indene ring $(\mathrm{C} 12-\mathrm{C} 20)$ is essentially planar [maximum deviation $=0.051(1) \AA$ for the $\mathrm{C} 13 \mathrm{atom}$ ] and is oriented at a dihedral angle of $44.9(1)^{\circ}$ with respect to tetrahydroisoquinoline unit.

The hydrogen bond geometry for compound (I) is presented in Table 2. In the crystal structure, intermolecular $\mathrm{C} 36-\mathrm{H} 36 \ldots \mathrm{O} 2$ contacts lead to the formation of $\mathrm{C}(10)$ supramolecular chain along $\mathrm{b}$ axis. These chains are linked into a double layer via intermolecular $\mathrm{C} 19-\mathrm{H} 19 \ldots \mathrm{Cg} 1^{\text {ii }}$ (symmetry code: (ii) $1-\mathrm{x}, 1 / 2+\mathrm{y}, 1 / 2-\mathrm{z}$ ) and $\mathrm{C} 21-\mathrm{H} 21 \mathrm{~A} \ldots \mathrm{Cg} 2^{\mathrm{iii}}$ (symmetry code: (iii) $1-\mathrm{x},-1 / 2+\mathrm{y}$, 1/2-z) hydrogen bonds [Fig. 2. and Table-2; $\mathrm{Cg} 1$ and $\mathrm{Cg} 2$ are the centroids of the (C22-C27) and (C28-C33) benzene rings, respectively]. The resulting double layer stacks along the $\mathrm{c}$ axis without any specific interactions (Fig. 3).

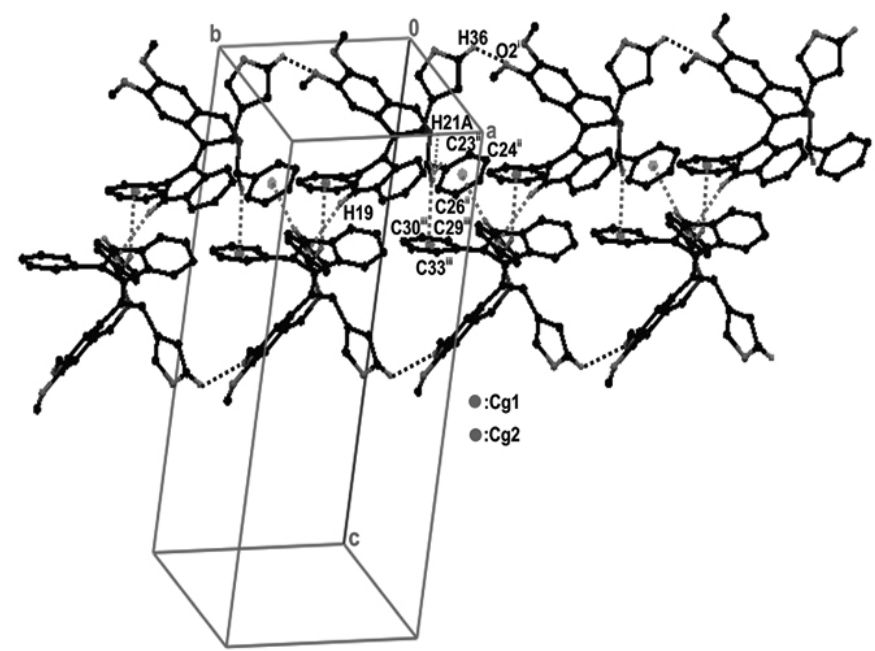

Figure 2:A view of the crystal packing showing supramolecular double layer along the $\mathrm{b}$ axis, mediated by $\mathrm{C}-\mathrm{H} . . . \mathrm{O}$ and $\mathrm{C}-\mathrm{H} \ldots \pi$ interaction. [ $\mathrm{Cg} 1$ and $\mathrm{Cg} 2$ are the centroids of the (C22-C27) and (C28-C33) rings, respectively, symmetry codes (i) $\mathrm{x},-1+\mathrm{y}, \mathrm{z}$ (ii) $1-\mathrm{x}, 1 / 2+\mathrm{y}, 1 / 2-\mathrm{z}$ (iii) $1-\mathrm{x},-1 / 2+\mathrm{y}, 1 / 2-\mathrm{z}$ ]. 


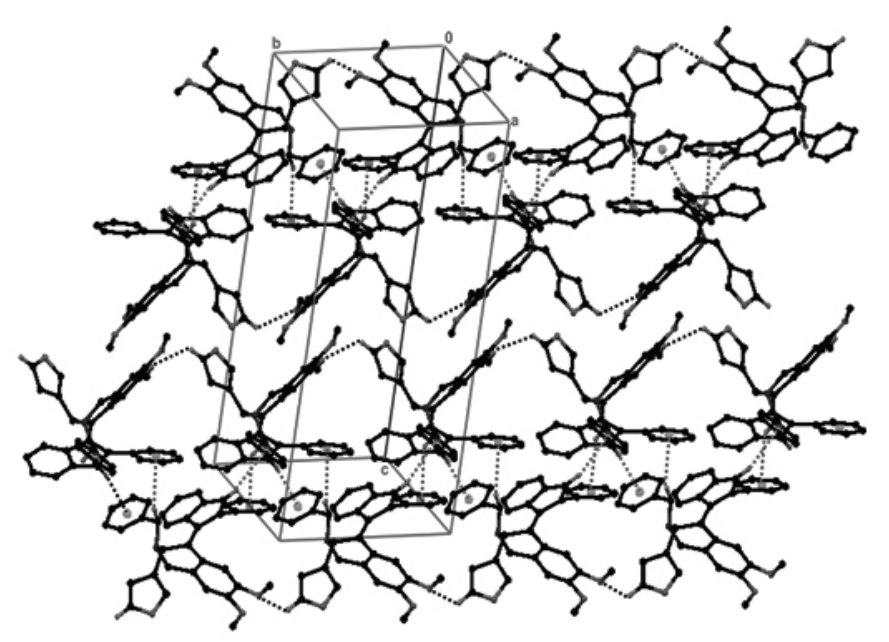

Figure 3: A view of the overall crystal packing highlighting the stacking of double layers along the $\mathrm{c}$ axis without any specific interactions

\subsection{DFT Calculations}

The first task of the computational work is to determine the optimized geometry of the title compound. The starting coordinates were obtained from $\mathrm{X}$-ray structure determination. The optimized parameters (bond lengths, bond angles) of the compound (I) were obtained using (DFT/B3LYP) method with the 6-311G(d,p) basis set. The results are listed in Table-3 and compared with the experimental data for the title compound. As seen from the Table- 3 , the agreement between the theoretically calculated and the experimentally obtained structure parameters for the title compound are very good. In view of the bond lengths in Table 3, most predicted values are longer than experimental ones. We note that the experimental results are for the solid phase and the theoretical calculations are for the gas phase. In the solid state, the existence of a crystal field along with the intermolecular interactions connect the molecules together, which results in the difference in bond parameters between the calculated and experimental values ${ }^{26}$.

TABLE 1. Crystal and experimental data for the compound (I).

\begin{tabular}{|l|l|}
\hline Empirical formula & $\mathrm{C}_{37} \mathrm{H}_{31} \mathrm{NO}_{3}$ \\
\hline Formula weight & 537.63 \\
\hline Temperature $(\mathrm{K})$ & $293(2)$ \\
\hline Wavelength $(\AA)$ & 0.71073 \\
\hline Crystal system & Monoclinic \\
\hline Space group & $\mathrm{P} 21 / \mathrm{c}$ \\
\hline Unit cell dimensions $\left(\AA{ }^{\circ}\right)$ & \multicolumn{2}{|c|}{${ }^{\circ}$} & $11.2121(4)$ \\
\hline$a$ & $10.4797(3)$ \\
\hline$b$ & $24.4375(9)$ \\
\hline$c$ & $98.174(2)$ \\
\hline$\beta$ & $2842.22(2)$ \\
\hline Volume $\left(\AA^{3}\right)$ & 4 \\
\hline$Z$ & 1.256 \\
\hline Calculated density $\left(\mathrm{Mg} / \mathrm{m}^{3}\right)$ & 0.079 \\
\hline Absorption coefficient $\left(\mathrm{mm}^{-1}\right)$ & 1136 \\
\hline F $(000)$ & $0.30 \times 0.26 \times 0.20$ \\
\hline Crystal size $\left(\mathrm{mm}^{3}\right)$ & 2.12 to 28.16. \\
\hline Theta range for data collection $\left({ }^{\circ}\right)$ & $-14<=h<=14,-13<=k<=13$, \\
\hline Index ranges & $-32<=l<=32$ \\
\hline Reflections collected & 51656 \\
\hline
\end{tabular}

\begin{tabular}{|l|l|}
\hline Independent reflections & $6950[\mathrm{R}(\mathrm{int})=0.0285]$ \\
\hline Completeness to theta $=28.16^{\circ}$ & $99.7 \%$ \\
\hline Absorption correction & Semi-empirical from equivalents \\
\hline Max. and min. transmission & 0.984 and 0.977 \\
\hline Refinement method & Full-matrix least-squares on $\mathrm{F}^{2}$ \\
\hline Data / restraints / parameters & $6950 / 0 / 372$ \\
\hline Goodness-of-fit on $\mathrm{F}^{2}$ & 1.018 \\
\hline Final R indices $[\mathrm{I}>2 \sigma(\mathrm{I})]$ & $\mathrm{R} 1=0.0434, \mathrm{wR} 2=0.1053$ \\
\hline R indices (all data) & $\mathrm{R} 1=0.0666, \mathrm{wR} 2=0.1217$ \\
\hline Largest diff. peak and hole $\left(\mathrm{e} . \AA^{-3}\right)$ & 0.183 and -0.222 \\
\hline
\end{tabular}

TABLE 2. Hydrogen bonding geometry for the compound (I) $\left(\AA,{ }^{\circ}\right)$.

\begin{tabular}{|l|c|c|c|c|}
\hline D-H...A & D-H & $\mathbf{d}(\mathbf{H} . . . A)$ & $\mathbf{d}(\mathbf{D} \ldots \mathbf{A})$ & $<$ (DHA) \\
\hline $\mathrm{C} 36-\mathrm{H} 36 \mathrm{~A} \ldots \mathrm{OO} 2^{\mathrm{i}}$ & 0.93 & 2.52 & $3.064(2)$ & 117.8 \\
\hline $\mathrm{C} 19-\mathrm{H} 19 \ldots \mathrm{Cg} 1^{1 \mathrm{ii}}$ & 0.93 & 2.73 & $3.631(2)$ & 164 \\
\hline $\mathrm{C} 21-\mathrm{H} 21 \mathrm{~A} \ldots \mathrm{Cg} 2^{\mathrm{iii}}$ & 0.97 & 2.87 & $3.717(2)$ & 146 \\
\hline
\end{tabular}

$\mathrm{Cg} 1$ is the centroid of the $\mathrm{C} 22-\mathrm{C} 27$ ring,

$\mathrm{Cg} 2$ is the centroid of the $\mathrm{C} 28-\mathrm{C} 33$ ring.

Symmetry codes : (i) $\mathrm{x},-1+\mathrm{y}, \mathrm{z}$; (ii) $1-\mathrm{x}, 1 / 2+\mathrm{y}, 1 / 2-\mathrm{z}$; (iii) $1-\mathrm{x},-1 / 2+\mathrm{y}, 1 / 2-\mathrm{z}$.

TABLE 3. Selected structural parameters by X-ray Diffraction and DFT calculations for compound (I).

\begin{tabular}{|c|c|c|}
\hline Parameters & X-ray & DFT \\
\hline \multicolumn{3}{|c|}{ Bond lengths $(\AA)$} \\
\hline $\mathrm{N} 1-\mathrm{C} 1$ & $1.454(2)$ & 1.460 \\
\hline C9-C34 & $1.495(2)$ & 1.508 \\
\hline $\mathrm{C} 8-\mathrm{C} 9$ & $1.519(2)$ & 1.534 \\
\hline $\mathrm{C} 8-\mathrm{C} 12$ & $1.362(2)$ & 1.374 \\
\hline $\mathrm{C} 4-\mathrm{O} 1$ & $1.361(2)$ & 1.355 \\
\hline $\mathrm{C} 10-\mathrm{O} 2$ & $1.413(2)$ & 1.421 \\
\hline C11-O1 & $1.411(2)$ & 1.421 \\
\hline $\mathrm{C} 4-\mathrm{C} 5$ & $1.407(2)$ & 1.421 \\
\hline $\mathrm{C} 5-\mathrm{C} 6$ & $1.365(2)$ & 1.382 \\
\hline $\mathrm{C} 3-\mathrm{C} 4$ & $1.370(2)$ & 1.388 \\
\hline \multicolumn{3}{|c|}{ Bond angles $\left(^{\circ}\right)$} \\
\hline C36-O3-C35 & $105.97(1)$ & 106.773 \\
\hline N1-C9-C34 & $109.03(1)$ & 110.446 \\
\hline N1-C21-C22 & $111.67(1)$ & 112.807 \\
\hline $\mathrm{N} 1-\mathrm{C} 1-\mathrm{C} 21$ & $115.06(1)$ & 113.916 \\
\hline $\mathrm{C} 5-\mathrm{O} 2-\mathrm{C} 10$ & $117.86(1)$ & 118.116 \\
\hline C19-C20-C28 & $122.90(1)$ & 120.914 \\
\hline C28-C20-C12 & $126.99(1)$ & 129.800 \\
\hline C33-C28-C20 & 121.51(1) & 119.682 \\
\hline C29-C28-C20 & $120.39(1)$ & 122.328 \\
\hline \multicolumn{3}{|c|}{ Torsion angles $\left({ }^{\circ}\right)$} \\
\hline N1-C21-C22-C23 & $146.68(2)$ & 139.176 \\
\hline N1-C21-C22-C27 & $-36.10(2)$ & -43.033 \\
\hline $\mathrm{C} 7-\mathrm{C} 8-\mathrm{C} 12-\mathrm{C} 13$ & $151.91(1)$ & 157.471 \\
\hline
\end{tabular}




\begin{tabular}{|c|c|c|}
\hline N1-C9-C34-C35 & $-119.18(2)$ & 129.426 \\
\hline C8-C9-C34-C35 & $3.60(2)$ & -5.346 \\
\hline
\end{tabular}

When the X-ray structure of the title compound was compared with its optimized counterpart (see Fig. 1), conformational discrepancies were observed. The orientation of the phenyl ring, furan ring attached to the tetrahydroisoquinoline of compound (I) proved the most notable discrepancy, and is defined with torsion angle $\mathrm{N} 1-\mathrm{C} 21-\mathrm{C} 22-\mathrm{C} 27=146.7(2)^{\circ}$ and $\mathrm{N} 1-\mathrm{C} 9-$ $\mathrm{C} 34-\mathrm{C} 37=59.5(2)^{\circ}$, which is calculated at $139.2^{\circ}$ and $53.2^{\circ}$, respectively, for B3LYP/6-311G(d,p) level.

As seen from Table 3 , the difference between the X-ray and calculated values for the bond lengths $\mathrm{C} 8-\mathrm{C} 9$ and $\mathrm{C} 10-\mathrm{O} 2$ are $0.015 \AA$ and $0.008 \AA$, respectively. Similarly, the difference for bond angles C28-C20-C12, C19$\mathrm{C} 20-\mathrm{C} 28$ and $\mathrm{N} 1-\mathrm{C} 21-\mathrm{C} 22$ are $2.81^{\circ}, 1.99^{\circ}$ and $1.14^{\circ}$, respectively. This difference is more due to intermolecular $\mathrm{C} 36-\mathrm{H} 36 \ldots \mathrm{O} 2$ hydrogen bond. According to experimental and calculated values, the dihedral angle between indene ring and phenyl ring attached to the tetrahydroisoquinoline is $58.7(1)^{\circ}$ and $55.6^{\circ}$, respectively.

A global comparison was performed by superimposing the molecular skeletons obtained from X-ray diffraction and the theoretical calculations atom by atom (Fig.4.), obtaining RMSE's values of $2.684 \AA$ for DFT/B3LYP) method with the $6-311 \mathrm{G}(\mathrm{d}, \mathrm{p})$ basis set. This magnitude of RMSE can be explained by the fact that the intermolecular columbic interaction with the neighboring molecules are absent in gas phase, whereas the experimental result corresponds to interacting molecules in the crystal lattice.

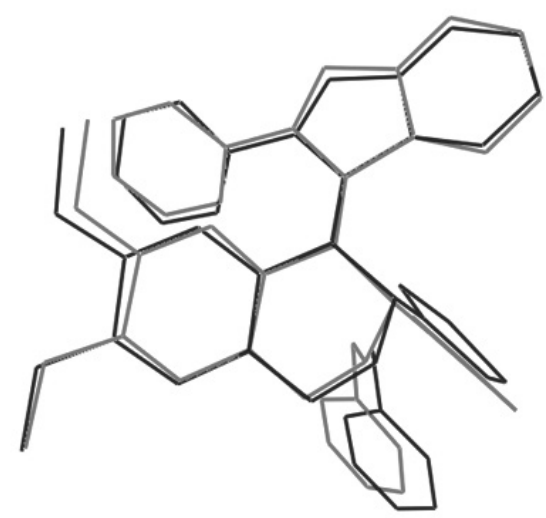

Figure 4: Atom-by-atom superimposition of the calculated structure (red) on the X-ray structure (blue) for compound

\subsection{Molecular orbital studies}

The most widely used theory by chemists is the molecular orbital (MO) theory. The frontier molecular orbitals play an important role in the electronic and optical properties, as well as in UV-VIS spectra and chemical reactions ${ }^{27}$. The DFT calculated electronic absorption spectra, the maximum absorption wavelength corresponding to the electronic transition is from the highest occupied molecular orbital (HOMO) to the lowest unoccupied molecular orbital (LUMO). The frontier molecular orbital energies of the title compound are shown in Fig 5.

The energy gap between HOMO and LUMO is a critical parameter in determining molecular electrical transport properties. ${ }^{28,29}$ The lowest unoccupied molecular orbital (LUMO) energy is $-2.0515 \mathrm{eV}$ and the highest occupied molecular orbital (HOMO) energy is $-5.3572 \mathrm{eV}$. The energy gap of HOMO-LUMO explains the ultimate charge transfer interaction within the molecule, and the frontier orbital energy gap of title compound is found to be $-3.3057 \mathrm{eV}$ obtained at DFT method using $6-311 \mathrm{G}(\mathrm{d}, \mathrm{p})$ basis set. Lower the HOMO-LUMO gap explains the eventual charge transfer interactions taking place within the molecule, which influences the biological activity of the molecule.

\subsection{Chemical reactivity}

Chemical reactivity indices like chemical hardness $(\eta)$, electronegativity $(\chi)$, electronic chemical potential $(\mu)$, and electrophilicity Index $(\omega)$, are calculated using DFT. Chemical hardness is associated with the stability and reactivity of a chemical system. In a molecule, it measures the resistance to change in the electron distribution or charge transfer. On the basis of frontier molecular orbitals, chemical hardness corresponds to the gap between the Highest Occupied Molecular Orbital (HOMO) and Lowest Unoccupied Molecular Orbital (LUMO). Chemical hardness is approximated using equation $\eta=\left(\mathrm{E}_{\text {LUмо }}-\mathrm{E}_{\text {номо }}\right) / 2$, where $\mathrm{E}_{\text {LUмо }}$ and $\mathrm{E}_{\text {номо }}$ are the LUMO and HOMO energies, respectively. The larger the HOMO-LUMO energy gap, the molecule will be harder, more stable and less reactive. Table 4 (row 4 ) contains the computed chemical hardness value for title compound.
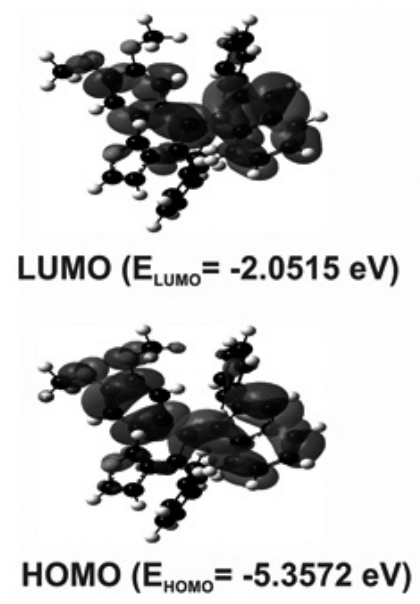

$\mathrm{E}_{\text {номо }}-\mathrm{E}_{\text {LUмо }}=-3.3057 \mathrm{eV}$

Figure 5: The molecular orbital and energies for the HOMO and LUMO of compound (I).

The concept of electronegativity put forward by Pauling ${ }^{30}$ is defined as "the power of an atom in a molecule to attract electrons towards itself". Higher is the electronegativity of the species, greater is its electron accepting power or rather the electrophilicity. Electronegativity is determined using equation $\chi$ $=-\left(\mathrm{E}_{\text {номо }}+\mathrm{E}_{\text {LUмо }}\right) / 2$, Table 4 (row 6 ) contains the computed electronegativity values for the title compound.

Electronic chemical potential is defined as the negative of electronegativity of a molecule $\mathrm{e}^{31}$ and determined using equation $\mu=\left(\mathrm{E}_{\text {номо }}+\mathrm{E}_{\mathrm{Huо}}\right) / 2$. Physically, $\mu$ describes the escaping tendency of electrons from an equilibrium system $^{32}$. The value of $\mu$ for the title compound is presented in Table 4 (row 5).

Global electrophilicity index $(\omega)$, introduced by Parr, is calculated using the electronic chemical potential and chemical hardness as shown in equation $\omega=$ $\mu^{2} / 2 \eta$. Electrophilicity index measures the propensity or capacity of a species to accept electrons ${ }^{33,34}$. It is a measure of the stabilization in energy after a system accepts additional amount of electronic charge from the environment ${ }^{35,36}$. The electrophilicity values of the title compound is presented in (Table 4, row 7).

The HOMO and LUMO orbital energies are related to gas phase ionization energies $(I)$ and electron affinities $(A)$ of the isomers according to the Koopmans' theorem through equations $A=-\mathrm{E}_{\mathrm{LUMO}}, I=-\mathrm{E}_{\text {номо }}$. Electron affinity refers to the capability of a ligand to accept precisely one electron from a donor.

TABLE 4. Calculated energy values of compound (1) by B3LYP/6$311 \mathrm{G}(\mathrm{d}, \mathrm{p})$.

\begin{tabular}{|c|c|}
\hline Basis set & B3LYP/6-311G(d,p) \\
\hline $\mathrm{E}_{\text {номо }}(\mathrm{eV})$ & -5.3572 \\
\hline $\mathrm{E}_{\text {LUмO }}(\mathrm{eV})$ & -2.0515 \\
\hline $\mathrm{E}_{\text {номо }}-\mathrm{E}_{\text {LUMO }}$ gap $(\mathrm{eV})$ & -3.3057 \\
\hline Chemical hardness $(\eta)$ & 1.6528 \\
\hline Chemical potential $(\mu)$ & -3.7043 \\
\hline Electronegativity $(\chi)$ & 3.7043 \\
\hline Electrophilicity index $(\omega)$ & 4.1511 \\
\hline
\end{tabular}

3.5 Molecular Electrostatic Potential

The Molecular Electrostatic Potential (MEP) is a plot of electrostatic potential mapped onto the constant electron density surface. The MEP has been used primarily for predicting sites and relative reactivity towards 
electrophilic attack, in studies of biological recognition and hydrogen bonding interactions $\mathrm{s}^{37,38}$. The negative electrostatic potential corresponds to an attraction of the proton by the concentrated electron density in the molecule (and is coloured in shades of red on the EPS surface), the positive electrostatic potential corresponds to repulsion of the proton by atomic nuclei in regions where low electron density exists and the nuclear charge is incompletely shielded (and is coloured in shades of blue). Potential increases in the order red $<$ orange $<$ yellow $<$ green $<$ blue

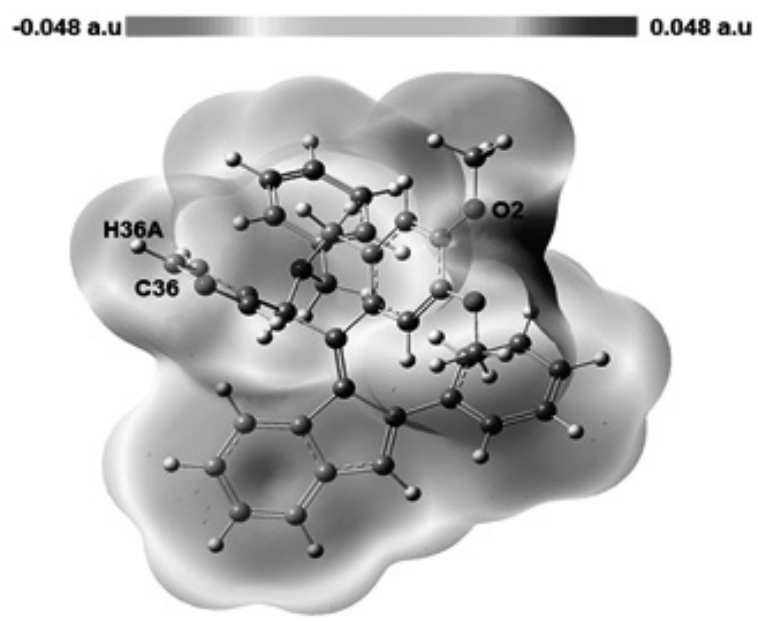

Figure 6: Molecular electrostatic potential map calculated using B3LYP/6-311G(d, p) level.

Figure 6 shows the molecular electrostatic potential (MEP), was determined using B3LYP/6-311G(d, p) method. The different values of the electrostatic potential at the surface are represented by different colours. As can be seen in Fig. 6, the negative (red) region is localized on the unprotonated atom of $\mathrm{O} 2$ with a minimum value of -0.0441 a.u. However, positive (blue) region is localized on atom $\mathrm{C} 36$ probably due to hydrogen, with a value of 0.042 a.u. Therefore, Fig. 6 confirms the existence of an intermolecular C36$\mathrm{H} 36 \mathrm{~A} . . . \mathrm{O} 2$ interaction.

\subsection{Interpretation of antibacterial activity}

Generally, a molecule with small Homo-Lumo energy gap is considered as a chemically reactive. The chemically reactive compounds are highly suitable for biological studies. From the DFT studies, a small Homo-Lumo energy gap
$(-3.3057 \mathrm{eV})$ depicts the chemically reactivity of the title compound (I) and hence it is highly suitable for biological studies. Hence, the title compound was tested for in vitro antibacterial activity studies.

Each zone size is interpreted by reference to the Table 2G (Zone Diameter Interpretative Standards and equivalent Minimum Inhibitory Concentration Breakpoints) of the NCCLS M100-S12: Performance Standards for Antimicrobial Susceptibility Testing: Twelfth Informational Supplement ${ }^{39}$ Results indicated that target compound exhibited significant antimicrobial activity against selected pathogens, Bacillus cerus , Escherichia coli, Pseudomonas aeruginosa, Staphylococcus aureus, Acinetobacter baumann, Staphylococcus epidermidis, Klebsiella pneumoniae and Proteus vulgaris when compared with the standard antibiotic ciprofloxacin $(25 \mu \mathrm{g})$.

TABLE 5. Antibacterial Activity of Compound at Different Concentrations against Bacterial Pathogens.

\begin{tabular}{|l|c|c|c|c|}
\hline \multirow{2}{*}{ Microorganisms } & \multicolumn{3}{|c|}{ Zone of inhibition (mm) } \\
\cline { 2 - 4 } & \multicolumn{2}{|c|}{ Compound Concentration } & \multirow{2}{*}{$\begin{array}{c}\text { Positive control } \\
\text { CIPX }(25 \mu \mathrm{g})\end{array}$} \\
\cline { 2 - 4 } & $(25 \mu \mathrm{g} / \mathrm{ml})$ & $(50 \mu \mathrm{g} / \mathrm{ml})$ & $(75 \mu \mathrm{g} / \mathrm{ml})$ & 38 \\
\hline Bacillus cereus (MTCC 430) & 18 & 22 & 25 & 30 \\
\hline Escherichia coli (MTCC 443) & 8 & 12 & 18 & 36 \\
\hline Pseudomonas aeruginosa (MTCC 1435) & 18 & 22 & 28 & 16 \\
\hline Staphylococcus aureus (MTCC 10623) & NI & 8 & 8 & 18 \\
\hline Acinetobacterbaumannii (MTCC 1425) & NI & 8 & 8 & 24 \\
\hline Staphylococcus epidermidis (MTCC 10623) & 22 & 25 & 25 & 35 \\
\hline Klebsiella pneumonia (MTCC 432) & 20 & 22 & 26 & 30 \\
\hline Proteus vulgaris (MTCC 742) & 18 & 22 & 27 & 35 \\
\hline
\end{tabular}

NI : No Inhibition, CIPX: Ciprofloxacin. Values are mean of three independent experiments

The most susceptible pathogens were Bacillus cereus, Pseudomonas aeruginosa $(28 \mathrm{~mm})$, Proteus vulgaris $(27 \mathrm{~mm})$, Klebsiella pneumoniae $(26$ $\mathrm{mm}$ ) and Staphylococcus epidermidis $(25 \mathrm{~mm})$ at concentration $75 \mu \mathrm{g} / \mathrm{ml}$ of the compound, exhibiting good antibacterial activity against these pathogens when compared to other pathogens studied, while 50 and $25 \mu \mathrm{g} / \mathrm{ml}$ concentrations of the compound exhibited moderate activity ranging from $18-25 \mathrm{~mm}$ in diameter for almost all pathogens as shown in Table 5. Figure 7 explains a bar diagram for the antibacterial activity. The present study concludes that the compound exhibited good to moderate antibacterial activity against all tested pathogens. 


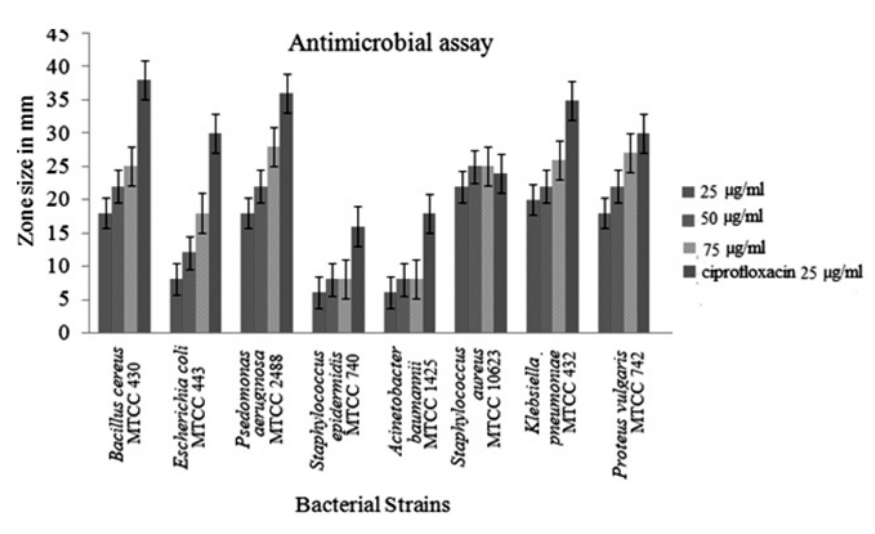

Figure 7: A bar diagram for the antibacterial activity for compound (I).

\section{CONCLUSION}

The title compound was synthesized and structurally characterized by elemental analysis, ${ }^{1} \mathrm{H}$ NMR and ${ }^{13} \mathrm{C}$ NMR and single crystal X-ray diffraction. In the crystal structure, supramolecular chains mediated by $\mathrm{C}-\mathrm{H}$... O contacts along the $\mathrm{b}$-axis are linked into a double layer via $\mathrm{C}-\mathrm{H} \ldots \pi$ hydrogen bonds. The resulting double layer stacks along the $\mathrm{c}$ axis without any specific interactions. To support the solid state structure, the geometric parameters of the title compound have been calculated using density functional theory DFT (B3LYP) method with the $6-311 \mathrm{G}(\mathrm{d}, \mathrm{p})$ basis sets, and compared with the experimental findings. It was noted here that the experimental results belong to solid phase and theoretical calculations belong to gaseous phase. In the solid state, the existence of the crystal field along with the intermolecular interactions have connected the molecules together, which result in the differences of bond parameters between the calculated and experimental values. The MEP map confirms the existence of intermolecular $\mathrm{C}-\mathrm{H}$... O interactions. The small HOMO-LUMO gap value shows that the molecule is biologically active. The obtained antibacterial activity results indicate that the compound exhibits good to moderate activity against all tested pathogens.

\section{Supplementary Materials}

CCDC 1021077contains the supplementary crystallographic data for this paper. This data can be obtained free of charge at http://www.ccdc.cam.ac.uk/ data request/cif, by e-mailing data request@ccdc.cam.ac.uk, or by contacting The Cambridge Crystallographic Data Centre, 12 Union Road, Cambridge CB21EZ, UK; fax: +44(0)1223-336033.

\section{ACKNOWLEDGEMENTS}

The authors thank Dr Babu Vargheese, SAIF, IIT, Madras, India, for his help with the data collection.

\section{REFERENCES}

1. P. S. Humphries, J. W. Benbow, P. D. Bonin, D. Boyer, S. D. Doran, R. K. Frisbie,

D. W. Piotrowski, G. Balan, B. M. Bechle, E. L. Conn, K. J. Dirico, R. M. Oliver, W. C. Soeller, J. A. Southers and X. Yang, Bioorg. Med. Chem. Lett., 19, 2400 (2009.)

2. K. Abe, T. Saitoh, Y. Horiguchi, I. Utsunomiya and K. Taguchi, Biol. Pharm. Bull., 28, 1355 (2005).

3. A. Storch, S. Ott, Y. I. Hwang, R. Ortmann, A. Hein, S. Frenzel, K. Matsubara, S. Ohta, H. U. Wolf and J. Schwarz, Biochem. Pharmacol., 63, 909 (2002).

4. J. W. Lane, A. Estevez, K. Mortara, O. Callan, J. R. Spencer and R. M. Williams, Bioorg. Med. Chem. Lett., 16, 3180 (2006).

5. A. E. Wright, D. A. Forleo, G. P. Gunawardana, S. P. Gunasekera, F. E. Koehn and O. J. McConnell, J. Org. Chem., 55, 4508 (1990).

6. A. M. Kamal, S. M. Radwan and R. M. Zaki, Eur. J. Med. Chem., 46, 567 (2011).

7. X. H. Liu, J. Zhu, A. N. Zhou, B.A. Song, H.L. Zhu, L.S. Bai, P.S. Bhadury and C. X. Pan, Bioorg. Med. Chem., 17, 1207 (2009).

8. K. Naveen, D. Muralidharan and P. T. Perumal, Eur. J. Org. Chem., 1172 (2014).
9. W. Koch and M.C.A. Holthausen, A Chemistry Guide to Density Functional Theory, Wiley-VCH, Weinheim, New York, Chichester, (2000).

10. R.G. Parr and R.G. Yang, Density Functional Theory of Atoms and Molecules, Oxford University Press, New York, USA, (1989).

11. Bruker, APEX-II, SAINT-Plus (Version 7.06a), BrukerAXS Inc. Madion, Wisconsin, USA, (2004).

12. G.M. Sheldrick, SHELXS97, A Program for Crystal Structure Solution, University of Göttingen: Germany (1997).

13. LJ. Farrugia, J. Appl. Cryst., 32, 837 (1999)

14. G.M. Sheldrick, SHELXL97, A Program for Crystal Structure Refinement, University of Göttingen: Germany (1997).

15. A.L. Spek, J. Appl. Cryst., 36, 7 (2003)

16. L.J. Farrugia, J. Appl. Cryst., 30, 565 (1997)

17. I.J. Bruno, J.C. Cole, P.R. Edgington, M.K. Kessler, C.F. Macrae, P. McCabe, J. Pearson and R. Taylor, Acta.Cryst., B58, 389 (2002)

18. A.D. Becke, J. Chem. Phys., 98, 5648 (1993)

19. C.T. Lee, W.T. Yang and R.G. Parr, Phys. Rev. B., 37, 785 (1988)

20. R. Ditchfield, W.J. Hehre and J.A. Pople, J. Chem. Phys., 54, 724 (1971)

21. R. Dennington II, T. Keith and J. Millam, Gauss View Version 4.1.2, Semichem Inc., Shawnee Mission, KS, (2007)

22. M.J. Frisch, G.W. Trucks, H.B. Schlegel, G.E. Scuseria, M.A. Robb, J.R. Cheeseman, J.A. Montgomery, T. Vreven Jr, K.N. Kudin, J.C. Burant, J.M. Millam, S.S. Iyengar, J. Tomasi, V. Barone, B. Mennucci, M. Cossi, G. Scalmani, N. Rega, G.A. Petersson, H. Nakatsuji, M. Hada, M. Ehara, K. Toyota, R. Fukuda, J. Hasegawa, M. Ishida, T. Nakajima, Y. Honda, O. Kitao, H. Nakai, M. Klene, X. Li, J.E. Knox, H.P Hratchian, J.B. Cross, C. Adamo, J. Jaramillo, R. Gomperts, R.E. Stratmann, O. Yazyev, A.J. Austin, R. Cammi, C. Pomelli, J.W. Ochterski, P.Y Ayala, K. Morokuma, G.A. Voth, P. Salvador, J.J. Dannenberg, V.G. Zakrzewski, S. Dapprich, A.D. Daniels, M.C. Strain, O. Farkas, D.K. Malick, A.D. Rabuck, K. Raghavachari, J.B. Foresman, J.V. Ortiz, Q. Cui, A.G. Baboul, S. Clifford, J. Cioslowski, B.B. Tefanov, G. Liu, A. Liashenko, P. Piskorz, I. Komaromi, R.L. Martin, D.J. Fox, T. Keith, M.A. Al-Laham, C.Y. Peng, A. Nanayakkara, M. Challacombe, P.M. W. Gill, B. Johnson, W. Chen, M.W. Wong, C. Gonzalez and J.A. Pople, Gaussian03, Gaussian Inc, Wallingford, CT, USA, (2004)

23. A. W. Bauer, W. M. M. Kirby, J. C. Sherris and M. Turck, Antibiotic susceptibility testing by a standardized single disk method. Am. J. Clin Pathol., 45, 493 (1966)

24. W. L. Duax, C. M. Weeks and D.C. Rohrer, Topics in Stereochemistry, Vol. 9, edited by E. L. Elliel \& N. Allinger, pp. 271-383. New York: John Wiley. (1976).

25. D. Cremer and J. A. Pople, J. Am. Chem. Soc., 97, 1354 (1975).

26. F.F. Jian, P.S. Zhao and Z.S. Bai, I. Zhang, Struct. Chem., 16, 635 (2005)

27. I. Fleming, Frontier orbitals and organic chemical reactions, London:Wiley, (1976)

28. K. Fukui, Science. 218, 747-754, (1982)

29. P. Udhayakala, T. V. Rajendiran, S. Seshadri, S. Gunasekaran, J. Chem. Pharm. Res.(3), 610-625, (2011)

30. L. Pauling, The nature of chemical bond, Cornell University Press, Ithaca, (1960)

31. R. G. Parr, R. G. Pearson, J. Am. Chem. Soc. 105, 7512, (1983)

32. P. K. Chattaraj, B. Maiti, J. Am. Chem. Soc. 125, 2705, (2003)

33. A. Vektariene, G. Vektaris, J. Svoboda, ARKIVOC. 7, 311, (2009)

34. R. G. Parr, L. Szentpaly, S. Liu, J. Am. Chem Soc. 121, 1922, (1999)

35. T. Koopmans, Physica. 1, 104, (1933)

36. S. Liu, J. Chem. Sci. 117, 477, (2005)

37. J. S. Murray, K. Sen, Molecular Electrostatic Potentials, Concepts and Applications, Elsevier, Amsterdam, pp 7-624, (1996)

38. E. Scrocco, J. Tomasi, Adv. Quant. Chem. 11, 115, (1978)

39. National Committee for Clinical Laboratory Standards (NCCLS), Performance standards for antimicrobial susceptibility testing; Twelfth informational supplement, Wayne, PA, M100-S12 (2002). 